\title{
Teachers` Perceptions of the Use of Electronic Learning Resources in Selected Secondary Schools, Marondera Urban, Zimbabwe
}

\author{
Richard Bukaliya $^{1 *}$, Jura Florence ${ }^{2}$ \\ ${ }^{I}$ Zimbabwe Open University, Mashonaland East Regional Campus Department of Teacher Development, P.O \\ BOX 758 Marondera, Zimbabwe \\ ${ }^{2}$ Zimbabwe Open University, Harare Chitungwiza Regional Campus. P.O. BOX MP1119, Mount Pleasant, \\ Harare, Zimbabwe
}

*Corresponding Author: Richard Bukaliya, Zimbabwe Open University, Mashonaland East Regional Campus Department of Teacher Development, P.O BOX 758 Marondera, Zimbabwe

\begin{abstract}
The purpose of this study was to explore the perceptions of teachers towards the use of e-resources in the teaching and learning of various subjects in selected high schools in Marondera District. A quantitative descriptive survey study approach was adopted, and data were collected through closed open-ended questionnaires. This study was concerned with the views of public high school teachers. Out of the 132 teachers, a sample of 50 respondents was selected. This accounted for $37.8 \%$ of the population. The sample was selected through simple random sampling in which two strata, according to gender, were used. From the teachers 'perspective, e-resources were global technological tools used in the teaching and learning process. Teachers perceived the use of e-resources in the teaching process as the best way to acquire resources in the teaching and learning of various subjects. Most respondents agreed that e-resources made learning interesting since it stimulates learner's interests. From the findings, the study recommended that teachers should provide guidance sessions so that learners can develop confidence in the use of e-resources. Teachers and learners need to undergo continuous in-service professional courses to enhance their computer literacy skills to help learners use e-resources. Parents should provide necessary e-resources for their children their children explore carrier options and find out what kind of education is needed to be successful in those careers. Government should embark on a programme in assisting schools to have access to internet service and donate e-resources in the high schools. Local book publishers should advocate for the use of e-resources in books and make their books accessible via the internet.
\end{abstract}

Key Words: perceptions, electronic learning resources, secondary schools

\section{BACKGROUND To THE STUdY}

With the rising costs of procuring basic textbooks and other teaching and learning resources, there is hope that internet-based resources could be the panacea to the problem. Most subjects in Zimbabwean school have been affected by the shortages resulting in alarming failure rates in these subjects. Baylor and Richie (2002) argue that the use of internet in class teachers and learners has an impact on students' content acquisition and class performance. Hungwe (2012) also adds that in Africa the use of educational electronic resources has been embraced with the aim of enabling learners to think creatively, solve problems, communicate effectively, identify, and analyse existing information.

The Ministry of Primary and Secondary Education (MOPSE), in Zimbabwe, requires the student to textbook ratio be 1:1 but situation on the ground depicts a gloomy picture where there is shortage of textbooks most schools, particularly the public schools. There is thus, need to solve the problem so that there is effective teaching and learning. The government of Zimbabwe introduced School Improvement Grant (SIG) and Better Schools Programme of Zimbabwe (BSPZ) to address textbook problems. Even United Nations Children Education Fund donated textbooks in 2012 but the limitations still exist. To empower learners with the use of e-resources, the government of Zimbabwe embarked on a massive drive to turn around the education sector by donating computers to many schools around the country and to train teachers on computer usage as well as introducing the updated curriculum. The implementation of the updated curriculum has brought many changes and is encouraging the use of information communication technology (ICT). 
Teachers' Perceptions of the Use of Electronic Learning Resources in Selected Secondary Schools, Marondera Urban, Zimbabwe

Innovation and implementations of e-resources in the classrooms tend to be accompanied by number of myths that have crept into folklore and belief systems noted by Sibthorpe and Soutr (2011).This is so in the political arena because new technologies when first introduced bring mixed feelings of fear anxiety and frustration. One of the Millennium Development Goals (MDS) highlighted by United Nations in 2000 is the importance of using internet as an educational tool. Higgins, Xiao and Katsipataki (2012) posits that technology in the $21^{\text {st }}$ century is a necessity such that any person who fails to learn and adapt to the rules of survival in the current environment risk facing the challenge of extinction(Hungwe, 2012).Though most high schools are lagging in use of e-resources, the proliferation of technologies has seen several schools adopting the use of e-resources in conjunction with the internet.

The effective implementation of the updated new curriculum usinge-resources has the capacity to enhance academic achievement among learners through collaboration, improved communication and sharing information. However, Kadzera (2006) contends that the availability of the e-resources and internet tools does not mean that effective learning will take place. In addition to availability of these tools, learning also depends on the situation, the users` creativity and attitude (Smith \&Nigel, 2009). Therefore, this study seeks to establish the perceptions teachers perceptions in the use of e-resources in the teaching and learning of various subjects in some selected high schools in Marondera Urban, Mashonaland East Province, Zimbabwe.

\section{Statement Of Problem}

The pass rate at both ordinary and advanced level has been below expectations with some stakeholders pinning the blame on learners` underperformance on lack of textbooks to read, teaching aids that are inadequate, and the pupil textbook ratio that is very high. Some schoolteachers and learners have been blamed for resistance towards the use of internet in the teaching and learning process despite the numerous benefits derived from their adoption. It is, therefore, important to establish teachers 'perceptions of the use of e-resources with a view to coming up with modalities meant to fully implement the use of these $21^{\text {st }}$ technology-based resources.

\section{RESEARCH QUESTIONS}

The study aimed at addressing the following research questions:

1. How do teachers perceive e-resources in the teaching and learning of different subjects in high schools?

2. How do teachers perceive learners`acceptance of the use of e-resources in the learning of various subjects in high schools?

3. Which e-resources are used in the teaching and learning processes in high schools?

4. What are teachers' views on the extent to which high schools can offer e-services for the instructional processes?

\section{REVIEW OF RELATED STUdies}

\subsection{Attitude of Teachers in the Use of Internet-Based Resources}

A research by Mlambo (2007) on internet-based resources used in 'A' level Physics teaching and learning at secondary schools in Manicaland Province, Zimbabwe revealed few teachers who even remembered when they last used e-resources in class, but they used printed textbooks and hardcopy journals. In line with this idea, Thompson (2000) in Enobun (2010) observed that some schools still use traditional teaching methods of teaching while others have seen the need to respond to thechangingworld. This means that in developing countries despite noted effectiveness of technology, not all teachers are competent and willing to use technology in their classes because of fear notes (Taiwawo, 2009).

E-resources such as computers make learning easier and less abstract as pictures and conversations are also downloaded and played on computers as visuals aids (Lal, 2002). This does not only make teaching and learning more conversational, but it makes it more practical and interesting (Suleiman, 2013). For instance, teaching the life set up of early Iron Age states. Videos on laptops downloaded on internet of people who existed during the Iron Age, makes the lesson real and more captivating 
Teachers' Perceptions of the Use of Electronic Learning Resources in Selected Secondary Schools, Marondera Urban, Zimbabwe

thereby increasing pupil's retention which is a benefit of using internet-based resources. However, the challenge is that teachers perceive the use of laptops during the teaching and learning process threatening their classroom authority and creates discipline problems (Reeves, 2009). Lal (2010) argues that a teacher without knowledgeable of e-resources cannot create change and progress as they require adaptability, flexibility effective use and communication skills to meet the instructional objectives. Thus, teachers whose attitudes disagree with the use of e-resources fear that they will be replaced by computers (Armstrong, 2011).

E-resources such as smart phones enable learners to share their opinions with each other thereby adding depth of understanding of a concept (Jonnassen et al.,2008). This allows learners to become more engaged in constructing their own knowledge thereby promoting their self- confidence and selfesteem. However, (Taiwawo, 2009) argues that this perspective is in male young teachers who are confident in this area as compared to older teachers and female counterparts. Safro and AnsongGyimah (2010) argue that the issue of gender and age does not affect teacher's perceptions towards the use of e-resources in the teaching and learning process. Safro and Anstrong-Gyimah (2010) argue that teachers remain afraid to adopt to use new approaches which they think might have negative impact on examination results as the examination is exam driven.

E-resources provide access to a wealth of information and enhanced communications transforming the teaching and learning process (Noeth\& Volkov, 2004). However, when learners are permitted into computer room for research on materials relevant to their subjects, they become more reluctant (Purcell et al., 2013). Some learners abused internet watching pornographic pictures, discuss issues related to politics and love affairs whilst others chat with their friends on the social media on e-tools. Thus, in class most teachers think that the use of internet on computers and laptops is a floodway for distractions (Chan et al., 2013) and they become reluctant to use some of the e-resources in the teaching and learning process.

To some teachers, the use of e-resources such as smart phones and laptops is a problem and time consuming as learners tend to concentrate much on laptops without paying attention (Safro\&AnsongGyimah, 2010). However, Griander (2006) posits that teachers have negative perceptions because of lack of exposure to lessons fully designed with e-resources and lack opportunities to try using the resource tools in class. Thus, as observed by Griander (2006) teachers should give themselves more time to learn on the use of e-resources in the teaching and learning process.

The use of e-resources in class needs a lot of preparation and time and teachers do not have time to spare for that (Taiwawo, 2009). Kadzera (2006) recognised shortage of planning time among teachers as one of the major restraining contributions of the use of e-resources in schools. However, others have shown that teacher backgrounds affect their perceptions towards the use of e-resources in the teaching and learning process (Griander, 2006). Teachers who learnt at high access schools had more positive attitude about e-resources ability to increase access to information and enhance communication than their counterparts from low access schools who tend to be concerned more about the ability of their learners in managing large amounts of information (Nomass, 2013). It has been advocated by Ring staff and Kelly (2002) that teachers need to spend a lot of time to find, assess, revise, and adjust learning materials, activities, and resources to fit to the needs of learners.

\subsection{Learners` Perceptions Towards the Use of E-Resources}

Kyriacou (2009) contends that learners learn more quickly and with greater retention when learning with educational technology tools instead of fostering inappropriate learning experience such as over reliance on rote memorisation. Prensky (2001) notes that digital natives have spent the rest of their lives surrounded by and using computers, digital music, cell phones and all other toys of digital age. Thus Ross et al. (2010) maintained that the digital culture and environment in which the learners had grown up had changed the way they think and the way they perceive teaching and learning. Learners tend to heavily rely on communication technologies to access information and dislike teaching or instruction by teachers (Ringstaff\& Kelley, 2002).

Lal (2002) posits that the Pew Internet and American life project conducted a research on the use of internet and found out that learners had a positive attitude towards the use of e-resources to do their schoolwork. In support with this perception, Ring staff and Kelley (2002) contend that with the access to e-resources and the internet, learners complete their schoolwork more quickly and their 
Teachers' Perceptions of the Use of Electronic Learning Resources in Selected Secondary Schools, Marondera Urban, Zimbabwe

assignments are drawn from up-to-date sources. However, (Armstrong, 2011) argues that learners perceptions about use of e-resources during the teaching and learning process is less positive because of lack of teacher's knowledge. Ringstaff et al. (2002) note that the introduction of internet-based and e-resources in the teaching and learning process gave teachers a chance for experimentation in class. This causes learners to have a negative perception towards the use of e-resources in the teaching and learning process.

E-resources bring about changes in the classroom roles and organisation as promotes learners to become more self-reliant and teachers functioning more as facilitators than lectures (Lal, 2002). For instance, the use of laptops and smart phones on the internet in the teaching and learning process, encourages discovery and independent learning thereby development of individual self-realisation or self-consciousness (Chaube\&Chaube, 2002). However, Oppenheimer (2003) argues that the availability of internet-based resources is not the obsolete resolution or important precondition to learners learning problem, learners who are doing less might feel intimidated as failures and can make less effort to succeed(Kyriaciou, 2009).

The use of e-resources such as computers enablelearners to have a strong interest to explore environment and to seek out stimulation (Musingafi\&Chaden'anga, 2014). This, therefore, helps in building their self-esteem and confidence in the learners. According to Suleiman (2013) notes that by using e-resources in teaching and learning and learning process learners feel good about themselves. Multu (2009) adds that if the e-resource is not attractive, the teacher will be wasting time as learners can shift their attention doing other activities instead of concentrating. Bhati (2011) concludes that without a knowledgeable the teacher uses of e-resources can be a waste of time and a hindrance to learning.

On one hand, the use of smart phones and other e-resources removes formality in the classroom thus the environment becomes conducive for learning allowing learners to remain focused during the teaching and learning process (Chan et al., 2013).On the other hand, Higgins et al. (2012) argue that the use of smart phones in class removes a sense of equality as learners come from different social backgrounds for some learners do not afford to purchase the phones thereby distracting the teaching and learning process. Armstrong (2011) notes that smart phones in the teaching and learning process are a source of delinquency, irritation, distraction, interruption and even crime.

\subsection{Internet Based Tools Used in the Teaching and Learning Process}

Previously, the tool kit of prior generations was a notebook and a pen; today's learners come to school armed with e-resources such as smart phones and laptops (Economist Intelligence Unit, 2008). Ndibalema, (2014) argues that secondary school teachers use computers, laptops, and smart phones as pedagogical tools. In support of this view, Carlson (2002) notes that today opportunities abound for learning through technological tools which include computers, smart phones, and laptops. This section aims to explain the internet-based resources used in the teaching and learning of religious studies regarding what they are and their use.

A smart phone, according to Chanetal. (2013), is a mobile phone that performs many functions of a computer, typically having a touch screen interface, video recorder, camera, internet access and operating system capable of running downloaded applications. Shelley et al. (2006) define a smart phone as an internet enabled telephone. The smart phone has a range of other electronic functions including those of a radio, MP3 player and camera which can have educational use(Subsother\&Souter, 2011). As has been argued, Purcell et al. (2013) note that a smart phone in a class can be used for looking up information on internet taking pictures, recording videos, sharing information on internet and texting in a class with other learners as part of assignment. A smart phone also allows learners to communicate using internet through electronic mail discussing and sharing ideas. This implies that smart phones in the teaching and learning process allow learners to chat, stay connected with peers, access application and receive information in time from around the world and learning beyond the four walls of classroom (Shelly et al., 2006).Norton (2009) asserts that chat groups are the fast way to distribute information to potentially interested readers and it allows people to discuss topics of common interest and find correct answers for questions. Thus, from the group discussion the teacher can identify areas of difficulty on learners. Since a chat group allows everyone to post not everything posted is correct but it promotes self confidence in learners, encourage learners 
Teachers' Perceptions of the Use of Electronic Learning Resources in Selected Secondary Schools, Marondera Urban, Zimbabwe

to contribute and work together thereby adding depth to learners learning experience (Shelly et al., 2006). Thus, this research examines advantages and constraints of using a smart phone in the teaching and learning process.

According to Shelly et al. (2006), a laptop is a portable, personal computer small enough to fit on your lap. Morley (2006) defines a laptop as a notebook computer capable of accepting data, processing it, giving it out and storing it for later use. Musingafi and Chiden'anga (2014) posit that the laptop has been found to be the most suitable and versatile medium for individualised learning, mass instruction and group learning because of its immense capacity as a data processor. With the use of a laptop learners can be connected to the internet and research any information they want to know. Teachers also use laptops to store information and research current information on the internet. Shelly et al. (2006) contend that the laptop can add depth to learners learning experience as it enables learners to research report papers using a wireless notebook computer. Thus, by use of laptops learners will be able to solve real life situations as they can face problems thereby perpetuating active and cooperative learning (Norton, 2009). However, it can be realised that the use of laptops causes learners to plagiarise as they prefer copy and paste (Morley, 2006).

According to Norton (2009), a computer is an electronic device which can receive information form and performing sequence of operations with a predetermined but variable set of procedural instructions to produce results in the form of information or signals. According to Shelly et al. (2006), a computer is a device that accepts information and manipulates it for some result based on a programme or sequence of instructions on how the data is to be processed. Morley (2006) contends that computers have reduced teacher's workload because they amplify the resources teachers' offers students, rather than relying on the textbook for content, computers can provide online access to content experts and up to date information from original sources. Though computers are offering learners a variety of real-world interactive learning experiences that can be replicated by other classroom tools however, this educational tool has created a gap between learners for some learners learn at schools which do not have computers because they cannot afford to purchase them, and some schools do not have electricity hindering the use of computers since they can only be used with electricity this cause the learners to be computer illiterate.

\subsection{The Extent to Which Schools Can Offer Internet Services}

The aim of internet-based resources is to facilitate access to opportunities and information. Morley (2006) posits that the electronic rate programme is aiming to streamline schools and libraries with internet services. In this order, the commission aims to ensure that all schools have access to highspeed connectivity and increases the electronic rate programme spending cap to adequately support that connectivity.

Schools in rural areas lack access to internet services because they do not afford to purchase internetbased resources such as computers. A study by Oppenheimer (2012) in KwaZulu Natal province in South Africa revealed that rural schools lack broadband infrastructure and high recurring costs of high-speed connections which are obstacles to achieve E-rate programme goals, rural schools are not connected to internet directly due to absence of telephones. Moreover, the areas are sparsely populated which is a challenge to provide connectivity in such areas and there is no infrastructure to put the wireless connections. Oppenheimer (2012) further explained that of the 71 schools in the vicinity of Manguzi only three have electricity and none have telephones to connect to either to the internet or the telecentre which becomes a hindrance for the schools to provide internet services.

Schools in rural areas face challenges to access to internet services because there are telecommunications infrastructures challenges such that installing modems, opening accounts with an internet service provider is difficult. A study by Oppenheimer (2012) in KwaZulu Natal province in South Africa revealed that rural schools lack broadband infrastructure and high recurring costs of high-speed connections which are obstacles to achieve E rate programme goals, rural schools are not connected to internet directly due to absence of telephones. Moreover, the areas are sparsely populated which is a challenge to provide connectivity in such areas and there is no infrastructure to put the wireless connections. Oppenheimer (2012) further explained that of the 71 schools in the vicinity of Manguzi, only three had electricity and none had telephones to connect to either to the internet or the telecentre which becomes a hindrance for the schools to provide internet services. 
Teachers' Perceptions of the Use of Electronic Learning Resources in Selected Secondary Schools, Marondera Urban, Zimbabwe

Higgins et al. (2012) posit that schools in urban areas have internet access they can use Wi-Fi since in towns there is electricity and telecommunications infrastructure. The only problem that affects internet access in urban areas is high cost of internet services and lack of electricity. Lal (2002) notes that there is uneven access to technology between the haves and the have nots. Nationwide schools that have not integrated technology often face basic problems, their internet connection is too weak and their laptops if they even have them too old to handle whole classrooms of students. A survey of schools by the Federal Communications (2014) half of the schools and libraries have lower speed internet connectivity.

\section{RESEARCH METHODOLOGY}

The study adopted the descriptive survey design for it aimed at revealing the actual picture of the situation through the emerging trends from area of study (Siverman, 2010). The survey investigated and gathered data from a portion of the population for purposes of examining the characteristics, opinions, and intensions of the population (Nunan, 2010). The population was drawn from a wide array of prospective respondents in the schools in Marondera District. The strength of the survey lay in broad the coverage, generalisation, comparability, and descriptive powers (Siverman, 2010).

\section{RESEARCH INSTRUMENTS}

The study adoptedquestionnaires as a tool for collecting and recording information about the teachers perceptions of the use of e-resources in the high schools. The researcher drafted closed ended questions which the respondents had to respond to in the write-up. Close ended questions were more easily analysed because these questions were more specific, thus more likely to communicate similar meanings among the various respondents. The instrument also made respondents to express their honest thoughts and opinions without the worry of being negative since they did not have to disclose their names (Menter et al., 2011).

\section{Population AND SAMPLe}

The study population entails the entire group of individuals, events or objects having common observable characteristics from which a sample which is a smaller group is obtained (Mugenda 2003). This study was concerned with the views of public high school teachers in Marondera Urban. As pass rates tended to be measured based on terminal examinations, only the advanced and o level final year teachers made up the population for the current study. Based on statistics from the randomly selected school, these were 132 prospective respondents to the study. Out of the 132 teachers, a sample of 50 respondents was selected. This accounted for $37.8 \%$ of the population. The sample was selected through simple random sampling in which two strata according to gender were used. Out of the 50 respondents, 29 were male whereas 21 were female high school teachers.

\section{Presentation And Discussion Of Findings}

The presentation of findings was premised on the research questions and discussion linked the findings of the current study with the reviewed literature and researcher's input. To establish the respondents` understandinge-resources, the questionnaire asked them to briefly demonstrate their understanding of the concept. Findings from most of the respondents show that they understand what was meant by e-resources. Most respondents45(90\%) defined e-resources as online technological tools used in the teaching and learning process with only a few being oblivious of the online issue. Most of these teachers were able to define e-resources in line with Reeves (2009) who defines eresources as technological tools used in the teaching and learning process. This helped to show whether teachers were aware of whate-resources were all about.

When asked what their attitude towards the use of e-resources, all the $50(100 \%)$ indicated positive responses. All the respondents had a positive attitude towards the use of e-resources. Safro and Ansong-Gyimah (2010) argue that the issue of gender and age does not affect teacher's perceptions towards the use of e-resources in the teaching and learning process. In line with this, Ndibalema (2014) asserts that secondary school teachers used smart phones, computers, and laptops as pedagogical tools. Hence, this shows that, most teachers had a positive attitude towards the use of eresources in the teaching and learning process.

The teachers were asked to comment on the attitude of learners towards the use of e-resources. Table 1 depicts the findings. 
Teachers' Perceptions of the Use of Electronic Learning Resources in Selected Secondary Schools, Marondera Urban, Zimbabwe

Table1. Teachers`perceptions of learners`attitudes towards the use of e-resources $(N=50)$

\begin{tabular}{|l|l|l|}
\hline Attitude of learners & Frequency & Percentage (\%) \\
\hline Fair & 43 & 86 \\
\hline Negative & 2 & 4 \\
\hline Positive & 5 & 10 \\
\hline TOTAL & $\mathbf{5 0}$ & $\mathbf{1 0 0}$ \\
\hline
\end{tabular}

Table 1 indicates the attitudes of learners from the teachers perspective, towards the use of eresources in the learning process. Some $43(86 \%)$ participants highlighted that learners had a fair attitude towards the use of e-resources. Two (4\%) indicated that learners had a negative attitude while $5(10 \%)$ respondents stated that learners had a positive attitude towards the use of e-resources in the teaching and learning of different subjects in curriculum. The findings demonstrate that learners had some interest in the use of e-resources. The findings resonate with the experiences of Kyriacou (2009) who contends that learners learn more quickly and with greater retention when learning with educational technology tools instead of fostering inappropriate learning experience such as over reliance on rote memorisation. In line with this, Puurcell et. al (2013) notes that, the learners who are digital natives, have spent the rest of their lives surrounded by and using computers, digital music, cell phones and all other toys of digital age. Thus Ross et al. (2010) maintains that the digital culture and environment in which the learners grow up changes the way they think and the way they perceive the use of e-resources in teaching and learning.

Teachers were also asked what electronic tools they used in the teaching process. Table 2 shows the findings.

Table2. E-resources used by teachers when teaching $(N=50)$

\begin{tabular}{|l|l|l|}
\hline Internet based resource tools & Frequency & Percent \% \\
\hline Desktop computer & 2 & 4 \\
\hline Cellular phone & 38 & 76 \\
\hline Laptops & 10 & 20 \\
\hline Total & $\mathbf{5 0}$ & $\mathbf{1 0 0}$ \\
\hline
\end{tabular}

Table2shows that 2 (4\%) respondentsuseddesktop computers to access e-resources. This can be attributed to the fact with power outages, most respondents found it very inconveniencing to use the desktop computers. That was why probably the majority $38(76 \%)$ found it very appropriate to resort to the use of their cell phones. The respondents felt comfortable in using smart phones as they could access a radio, MP3 player and camera which could be used for educational purposes. As has been argued by Purcell et al. (2013), smart phones in a class could be used to look up for information on internet, taking pictures, recording videos, sharing information on internet and texting in a class with other learners as part of assignment. A smart phone also allowed teachers to communicate using internet through electronic mail discussion groups thus sharing ideas. This implies that smart phones in the teaching and learning process allowed learners to chat, stay connected with peers, access application and receive information in time from around the world and learning beyond the four walls of classroom (Shelly et al., 2006).However, Armstrong (2011) argues that smart phones are a source of irritation, distraction, interruption, delinquency and even crime in class. The 10 (20\%) indicated that they used using laptops in the teaching and learning process since laptops has a battery life that lasted long, could conserve power after power outages and were portable. According to Shelly et al. (2006), a laptop is a portable, personal computer small enough to fit on one`s lap. However, Safro and Ansong-Gyimah (2010) argue that using laptops in classroom is time consuming as learners tend to concentrate much on laptops without listening.

Teachers were also asked to state how their learnersperceivede-resources in the teaching and learning process. Findings show that all $50(100 \%)$ teachers indicated that the learners had a positive perception towards the use of e-resources. The50 (100\%) respondents highlighted that according to their learners, e-resources were the best resources in the teaching and learning process. Lal (2002) posits that the Pew Internet and American life project conducted a research on the use of internet and found out that learners have a positive attitude towards the use of internet to do their schoolwork. In support with this perception, Ringstaff and Kelley (2002) contend that with the access of internet learners complete their schoolwork more quickly and their assignments are drawn from up-to-date 
Teachers' Perceptions of the Use of Electronic Learning Resources in Selected Secondary Schools, Marondera Urban, Zimbabwe

sources. Suleiman (2013) notes that by using e-resources in teaching and learning and learning process learners feel good about themselves. Thus, Ross et al. (2010) maintained that the digital culture and environment in which the learners had grown up had changed the way they think and the way they perceive teaching and learning.

In line with the research questions, the teachers` questionnaire wanted to establish the capability of the high schools in providing internet services. Figure 1 below depicts the findings.

$(N=50)$

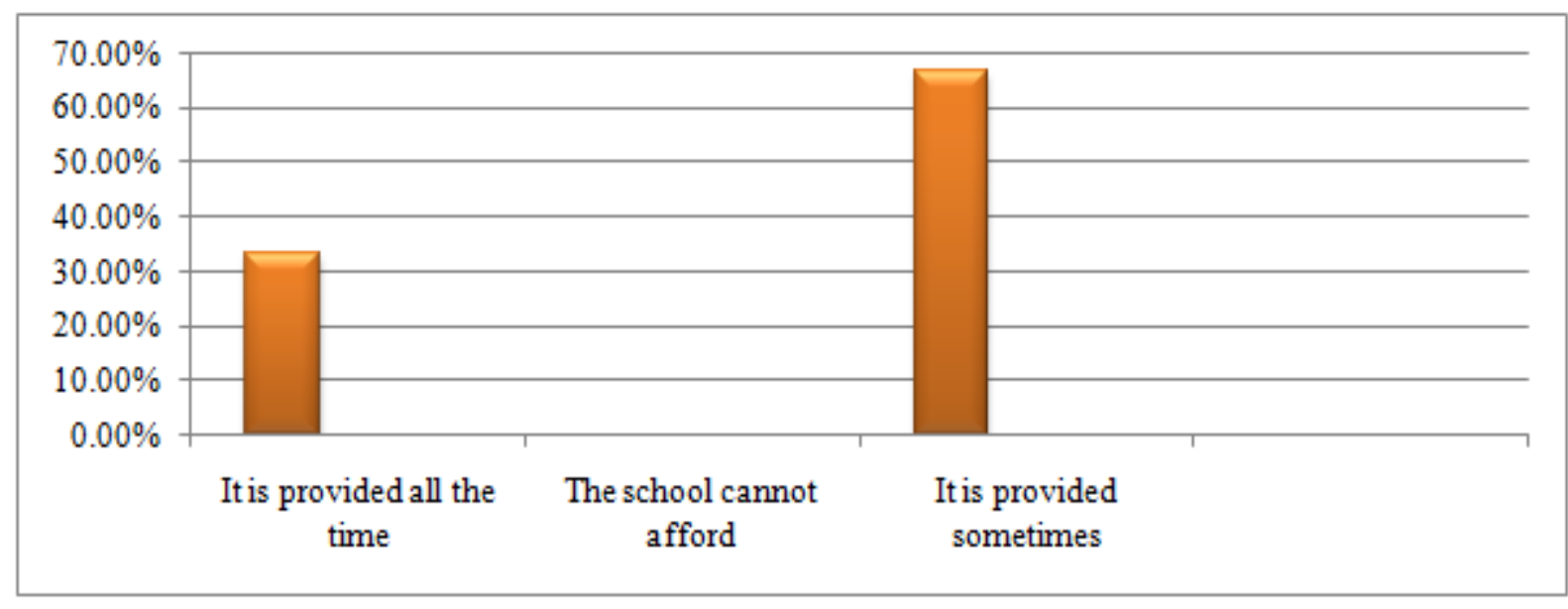

Figure1. The capacity of the high schools to provide internet services

Figure 2 shows that $67 \%$ of the respondents indicated that internet was sometimes provided implying that it was not readily available all the time. This may be caused by the broadband data that would be exhausted and poor internet signals. Some $33 \%$ of the respondents stated that the internet was provided by the school all the time. However, this scenario seems not to auger well for the process of streamlining schools and libraries with internet services (Morley, 2006).All the schools need to ensure that teachers and learners have access to high-speed connectivity for improved access to internetbased resources.

Accessibility to the internet services was also another issue that needed to be explored by the study. Teacher respondents were asked how accessible the internet services were in the different high schools. Table 3 shows the results.

Table3. Accessibility of internet services $(N=50)$

\begin{tabular}{|l|l|l|}
\hline Internet access & Distribution & Percentage (\%) \\
\hline Very accessible & 0 & 0 \\
\hline Accessible & 33 & 66 \\
\hline Limited access & 17 & 34 \\
\hline Total & 50 & 100 \\
\hline
\end{tabular}

From Table 3, $33(66 \%)$ teachers agreed that the internet was accessible at their high schools. However, some 17(34\%) respondents noted that there was limited access of internet and, according to the teachers, this was caused by weak internet strength, electricity-power cuts as well as cloud cover and broadband data exhaustion. The situation depicted in the different schools was also highlighted by Lal (2002) who noted that there was uneven access to technology between the haves and the have not. Nationwide schools that have not integrated technology often face basic problems, their internet connection is too weak and their laptops if they even have them, they are too old to handle whole classrooms of learners.

It was also pertinent to establish the use of the internet by teachers in teaching and learning. Figure 3 depicts the responses.

$(\mathrm{N}=50)$ 
Teachers' Perceptions of the Use of Electronic Learning Resources in Selected Secondary Schools, Marondera Urban, Zimbabwe

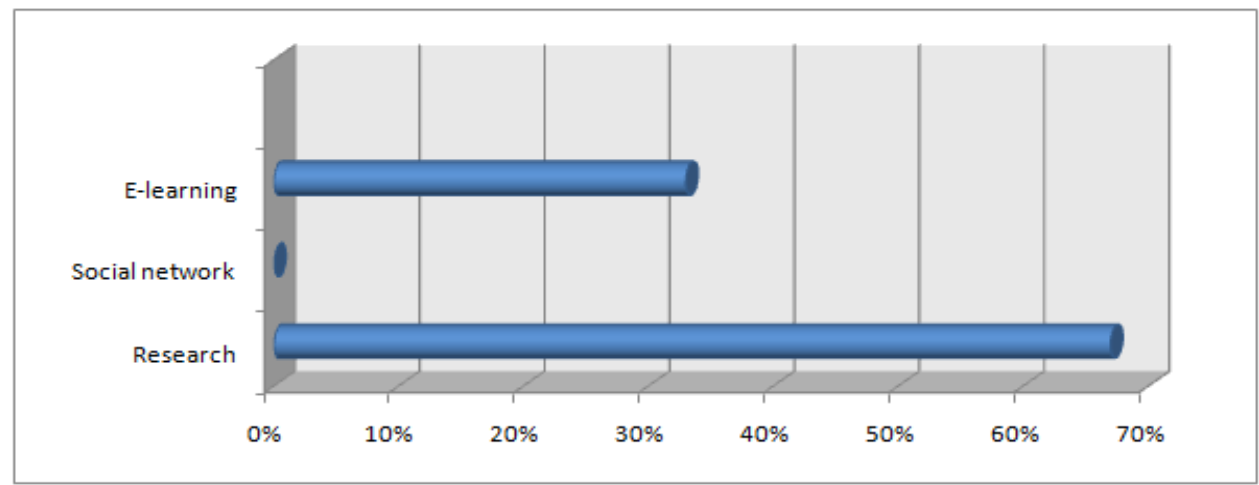

Figure3. Uses of internet resources by teachers in teaching and learning

From Figure3, 67\% of the respondents highlighted that internet was mostly used for research in the teaching and learning process. Thirty-three percent of the teachers noted that internet was mostly used for e-learning. None of the respondents indicated that internet was used for social networking. Internet based resources provide access to a wealth of information and enhanced communications transforming the teaching and learning process that could be tapped for instructional purposes (Noeth\& Volkov, 2004). Norton (2009) contends that for educational purposes the function of internet to explain abstract concepts and visual experimentation is important in making abstract concepts understandable. Teacher's views were in line with Musingafi and Chaden'anga (2013) who note that e-resources, if properly used, lead to efficiency and effectiveness in the teaching and learning process. It was also refreshing to note that teachers were not in the habit of using the internet for personal social networking especially at school.

Teachers` views were also sought on the benefits of the internet for the learners. Results obtained are shown in the following figure.

$(\mathbf{N}=\mathbf{5 0})$

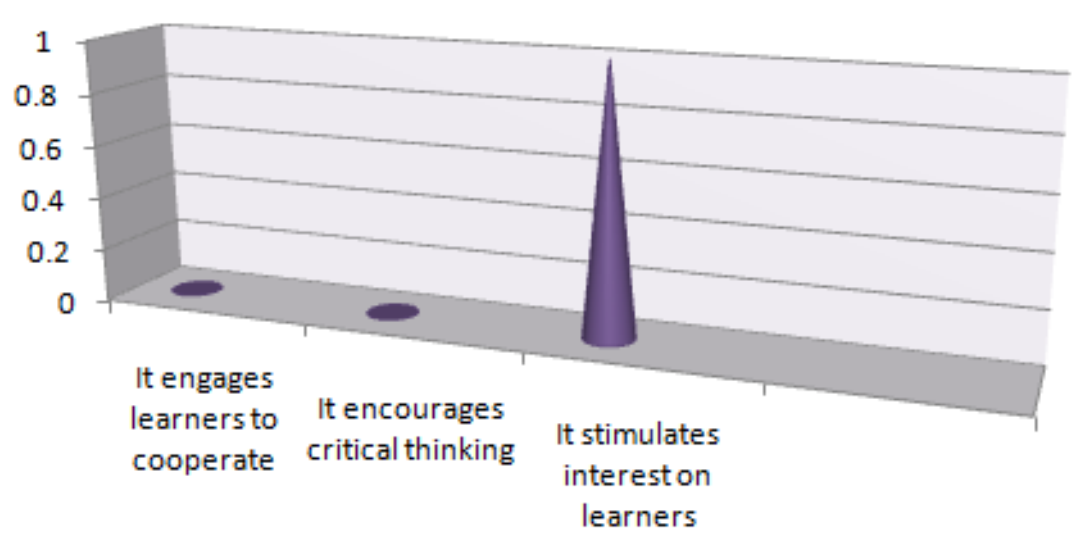

Fig4. Benefits of the internet for the learners

Data presented on Figure 4 above shows that the majority of the $100 \%$ of teachers strongly agreed to the fact that the internet made learning interesting since it stimulated interest in learners. In line with the above, the use of internet resources enabled learners to have a strong interest to explore environment and to seek out stimulation contends (Musingafi\&Chaden'anga, 2014). This helped build their self-esteem and confidence. Supporting this view, Suleiman (2013) notes that by using internet resources in the teaching and process, learners feel good about themselves.

Findings also indicated that $100 \%$ of the teachers agreed to the fact that the use of internet resources made teaching and learning process easier since teachers and learners could research on new topics in the various subjects. In line with teachers' views, Norton (2009) contends that for educational purposes the function of internet to explain abstract concepts and visual experimentation is important in making abstract concepts understandable. Internet based resources provided access to a wealth of 
information and enhanced communications transforming the teaching and learning process (Noeth\& Volkov, 2004). Moreover, Ring staff and Kelley (2002) contend that with the access of internet, learners complete their schoolwork more quickly and their assignments are drawn from up-to-date sources. Suleiman, (2013) notes that by using internet resources in teaching and learning process learners feel good about themselves.

\section{MAJOR RESEARCH FINDINGS}

The following were the major findings of the study:

- Some $67 \%$ of the teachers agreed that e-resources were global technological tools used in the teaching and learning process whilst 33\% defined e-resources as means of imparting knowledge to learners and viewed e-resources as internet used in teaching and learning process to develop desirable qualities in learners.

- Most of the teachers indicated that cell phones were mostly used e-resources in the teaching and learning of whilst 33\% favoured laptops as the most used electronic tool in the teaching and learning processes in high schools.

- All (100\%) teachers perceived the use of e-resources in the teaching process as the best way to acquire resources in the teaching and learning of various subjects.

- Sixty-seven percent agreed that internet was used mostly for research whilst $33 \%$ noted that internet was widely used for e-learning purposes in the teaching and learning process.

- The majority of $100 \%$ strongly agreed that internet-based resources made learning interesting since it stimulates learner's interests.

- From the teachers ' perspectives, most teachers and learners had a positive attitude in the use of eresources as well as internet-based resources in different subjects.

- Some $20 \%$ agreed that internet-based resources promoted self-confidence whilst the other $20 \%$ agreed that the e-resources promoted self-motivation. The majority of $60 \%$ indicated that the use of e-resources promoted knowledge and skills acquisition among the teachers and learners.

- Most of the teachers highlighted that the internet was accessible and only $33 \%$ noted that there was limited access of internet services in the high schools.

- According to the majority of 55\%teachers, learners benefited computer literacy skills with the introduction of computers. Some $25 \%$ highlighted that learners benefitted through critical thinking skills whilst $25 \%$ benefitted problem-solving skills.

- The majority $100 \%$ of teachers agreed that the use of e-resources made teaching and learning easier since teachers and learners can research easily on new topics in history.

\section{CONCLUSION}

The following conclusions were drawn from the findings. Based on the research findings in the study concludes that:

- E-resources are used in the teaching and learning processes in high schools.

- The e-resources in use in the high schools include computers, laptops, and smart phones.

- From the mentioned internet resources teachers prefer to use laptops and cell phones whereas learners preferred to use computers and smart phones.

- Internet-based resources help in making teaching easier and in promoting learners` selfconfidence.

- Internet based resources improve learner's ability to critically analyse facts.

- Internet based resources are helpful in meeting learners with different abilities.

- Learners perceive that internet-based resources can help them to learn better than a teacher. This shows that learners are determined to use internet-based resources to acquire knowledge in this era of information age. 
Teachers' Perceptions of the Use of Electronic Learning Resources in Selected Secondary Schools, Marondera Urban, Zimbabwe

- E-resources have a positive impact in the teaching and learning in high schools for they enable learners to improve on critical analysis.

\section{RECOMMENDATIONS}

From the findings, the following were the recommendations:

- Teachers should provide guidance sessions so that learners can develop confidence in the use of eresources.

- Teachers and learners need to undergo continuous in-service professional courses to enhance their computer literacy skills to help learners use e-resources.

- Teachers and learners should have a positive attitude towards the use of e-resources.

- Learners should actively make use of the e-resources and internet services at the school.

- Parents should provide necessary e-resources for their children their children explore carrier options and find out what kind of education is needed to be successful in those careers.

- Government should embark on a programme in assisting schools to have access to internet service and donate e-resources in the high schools.

- Government should support teachers in the use of e-resources and with resources permitting, MOPSE should provide scholarships to teachers who wish to support further education in ICT based programmes.

- Local book publishers should advocate for the use of e-resources in books and make their books accessible via the internet.

\section{REFERENCES}

[1] Almekhlafi, A. G. \&Almeqddadi, F. A. (2010).Teachers` perceptions of technology integration in the United Arab Emirates school classrooms', Educational Technology and Society, 13 (1), 165-175.

[2] Annum, G. (2015).Research instruments for data collection. At http://www.LupaneStateUniversity/ com/newdiart/file/php/1/gii/madstore/Ugradresearch/ThesisWrit4911/File/notes/res/nst.pdf/ (Accessed 18 August 2020).

[3] Baylor, A. L.and Ritchie, D. (2002). What factors facilitate teacher skill, teacher morale, and perceived student learning in technology using classrooms?'.Computer and Education. 39(5), 395-414.

[4] Beggs, T. A. (2000).Influences and barriers to the adoption of internet resources. At http://www. ifets.info/journals/12 1/15.pdf(Accessed 05 August 2020).

[5] Bhati, M. S. (2011). "The role of ICT in teaching Social Studies", Indian Streams Research. I (4) [Inter net].athttp://www org/Uploaded Data/153pdf.(Accessed 24 August 2020).

[6] Carlson, S. (2002). The missing link in educational technology: Trained teachers. At http://www. techknowlogia.org/TKL Articles/PDF/435.pdf. (Accessed 21 September 2020).

[7] Chan, N. N., Walker, A. \&Remedios, R. (2013). Ubiquitous learning: The lived experience of students learning with smart phones. At http;//inc-m.t.edu/linc 2013/proceedings/session 2 Chan -pdf. (Acce ssed 22 July 2020).

[8] Chaube, S.P. \&Chaube, A. (2002).Foundations of education. New Delhi: Viras Publishing House.

[9] Economist Intelligence Unit. (2008).The future of higher education: How technology will shape learning. New York: The Economist Intelligence Unit.

[10] Enonbun,O. (2010). Constructivism and Web 2.0 in the emerging learning era: A global perspective. Athttp://www.n9.bussinesspress.com/JSIS/EnobunWeb.pdf(Accessed 2 March 2021).

[11] Fayel, A. \& AL-Zube, M. (2013).The difference between learner centred approach and the teacher centred approach in teaching English as a foreign language. At http://www.erint.savap.org.pk/PDF/Vo 1.2(2)/ER/nt.2013(2-2-04) pdf (Accessed 30 March 2020).

[12] Fink, C.T. (2010).Conducting research literature reviews. London: Sage Publications, Inc.

[13] Griander, H. (2006). How technology leads to improved student achievement. At http://www.ncs/org/ portals/1/documents/educ/item013161.pdf. (Accessed 17 October 2020).

[14] Higgins, S., Xiao, Z.\&Katsipataki, M. (2012).The impact of digital technology on learning: A summary for the Education Endowment Foundation. Durham: Durham University.

[15] Hungwe, K. N. (2012). Raising questions about the place of computer technologies in Zimbabwe. Athttp://archieve.lib.msu.edu/DMC/African\%2520Journals/pdf.(Accessed 21 August 2020). 
Teachers' Perceptions of the Use of Electronic Learning Resources in Selected Secondary Schools, Marondera Urban, Zimbabwe

[16] Menter, I., Elliot, D., Hulme, M., Lewin, J.\&Lowden, K. (2011). A guide to practitioner research in education. London: Sage Publications Ltd.

[17] Morley,D. (2006).Computers and technology in a changing society. Boston: Thompson Course Technology.

[18] Mugenda, O. M. \& Mugenda, A. G. (2009).Research methods: Quantitative and qualitative approaches. Nairobi: Acts Press.

[19] Musingafi, M. C. C.\&Chaden'anga, C. (2014). Information and Communication Technology in Classroom situations in rural and urban Areas in Zimbabwe: A comparative Study on the Use of digital and Projected Media in Teaching and learning at Six secondary Schools in Masvingo. Athttp://www.parkinsight. com/pdf-files/RIEA-2014-1(4)-77-(@.pdf (Accessed 06 July 2020).

[20] Ndibalema, P. (2014). Teachers' attitude towards the use of Information Communication Technology (ICT) as a pedagogical tool in secondary schools in Tanzania: The Case of Kondona District. International Journal of Education Research, 2 (2): 15-26.

[21] Noeth, R.J. \& Volkov, B. B. (2004). Evaluating the effectiveness of technology in our schools. At https:// www.act.org/research/policymakers/pdf/school tech.pdf. (Accessed 06 September 2020).

[22] Nomass, B. B. (2013). The impact of using technology in teaching English as a second language, English Language Literature Studies.3(1), 116-116.

[23] Norton, P. (2009).Peter Norton's Computing Fundamentals. New York: McGraw Hill.

[24] Nunan, D. (2010). Research methods in language learning. Cambridge: Cambridge University Press.

[25] Oppenhimer, T. (2003). The flickering mind: False promise of technology in the classroom and how learning can be saved. New York: Random House.

[26] Purcell, K., Heaps, A., Buchanan. J. \& Fredrick, L. (2013). How teachers are using technology at home and in their classrooms. At http://www.perwinternet.org/files/oldmedia/files/Reports/ 2013/PIP. Teachers and Technology with Methodology- PDF.pdf (Accessed 15 August 2020).

[27] Reeves, L. C. (2009). The impact of media and technology in schools. European Educational Research Journal, 4(2), 5-21.

[28] Ring staff, C. \& Kelly, L. (2002). The learning return on our internet resources: A Review of Findings from Research. San Francisco: CA West Ed RTEC.

[29] Ross, S., Morrison, G. R.\& Lowther, D. L. (2010). Educational technology research past and present: Balancing rigor and relevance to impact school learning. Contemporary Educational Technology, 1(1), 17-35.

[30] Sarfo, F. K. \&Ansong-gyimah, K. (2010). The perceptions of students, teachers, and educational officers in Ghana on the role of computer in promoting the First Five Principles of Instruction. At http://www. tojet.net/articles/v9i3/938.pdf \{ Accessed 23 July2015].

[31] Sibthorpe, C. and Souter, D. (2011). Transformation-Ready: The strategic application of information and communication technologies in Africa. At http;//siteresources.worldbank.org/ext information and communication and technologies/Res ources/282822-1346223280837/Education Fullreport. Pdf. (Access ed 26 August 2020).

[32] Shelly, G. B., Cashman, T. J. \& Gunter, R. E. (2006). Teachers discovering computers integrating technology and digital media in the classroom. Boston: Thompson Course Technology.

[33] Silverman, D. (2010).Doing Qualitive Research. London: Sage Publications.

[34] Smith, H. R. \& Nagel, T. S. (2008). Instructional Media in The Learning Process. Columbus: $\mathrm{OH}$ : Charles E. Merrill.

[35] Suleiman, N. (2011). The use of mobile phones in learning English language by sultan Gaboos university students: Practice, attitudes and challenges. Canadian Journal on Scientific \& Industrial Research.2 (3), 143-153.

[36] Taiwawo, S. (2009).Teachers 'perception of the role of media in classroom teaching in secondary schools. A thttp://www.tojet.net/articles/v8i1/818.pdf. (Accessed 22 August 2020).

Citation: Richard Bukaliya, Jura Florence. "Teachers' Perceptions of the Use of Electronic Learning Resources in Selected Secondary Schools, Marondera Urban, Zimbabwe" International Journal of Humanities Social Sciences and Education (IJHSSE), vol 8, no. 7, 2021, pp. 26-37. doi: https://doi.org/10.20431/2349. 0381.0807004.

Copyright: (C) 2021 Authors. This is an open-access article distributed under the terms of the Creative Commons Attribution License, which permits unrestricted use, distribution, and reproduction in any medium, provided the original author and source are credited. 